\title{
The Values of Public Library in Promoting an Open Government Environment by Djoko Sayogo
}

Submission date: 24-Mar-2019 07:52PM (UTC-0700)

Submission ID: 1099097015

File name:f_Public_Library_in_Promoting_an_Open_Government_Environment.pdf (674.56K) Word count: 8276

Character count: 45339 


\section{The Values of Public Library in Promoting an Open Government Environment}

\author{
Djoko Sigit Sayogo \\ University of Muhammadiyah Malang \\ Jl. Raya Tlogomas no. 246 \\ Malang, Indonesia \\ dsayogo@umm.ac.id
}

\author{
Shaohui Wang \\ School of Politics and Public \\ Administration, Wuhan University \\ 299 BaYi Road, Wuhan City, China \\ shwang01@163.com
}

\author{
Sri Budi Cantika Yuli \\ University of Muhammadiyah Malang \\ Jl. Raya Tlogomas no. 246 \\ Malang, Indonesia \\ cantikayuli@gmail.com
}

\begin{abstract}
Public participation has been less than ideal in many governmentimplemented ICT initiatives. Extant studies highlight the importance of public libraries as an intermediary between citizens and government. This study evaluates the role of public libraries as mediating the relationship between citizens and government in support of an open government environment. Using data from a national survey of "Library and Technology Use" conducted by PEW Internet in 2015, we test whether a citizen's perception of public values provided by public libraries influence the likelihood of the citizen's engagement within open-govemment environment contexts. The results signify a significant relationship between certain public values provided by public libraries with the propensity of citizens engaging government in an online environment. Our findings further indicate that varying public values generate different results in regard to the way citizens are stimulated to use public libraries to engage with government online. These findings imply that programs designed and developed to take into account a variety of values are more likely to effectively induce citizen engagement in an open government environment through the mediation of public libraries.
\end{abstract}

\section{CCS Concepts}

- social and professional topics - technology policy government technology policy - governmental regulations

\section{Keywords}

"public libraries", "open government", "public values", "citizens engagement", "e-government".

\section{INTRODUCTION}

"If you build it, they will come." This famous line from the movie, Field of Dreams, reflects the underlying premise of many government ICT investments. Alas, public participation in many government ICT investments, such as open government and open data, has been underwhelming. Many initiatives assume that

Permission to make digital or hard copies of all or part of this work for personal or classroom use is granted without fee provided that copies are not made or distributed for profit or commercial advantage and that copies bear this notice and the full citation on the first page. Copyrights for components of this work owned by others than ACM must be honored Abstracting with credit is permitted. To copy otherwise, or republish, to post on servers or to redistribute to lists, requires prior specific permission and/or a fee. Request permissions from Permissions $a$ acm.org.

dg.o '16, June 08-10, 2016, Shanghai, China

C 2016 ACM. ISBN $978-1-4503-4339-8 / 16 / 06 \ldots \$ 15.00$

DOI: http://dx.doi.org/10.1145/2912160.2912199 citizens will be willing and interested to participate once the ICT project is developed [11].

Open government and open data has been criticized for focusing more on the supply side and less on the demand side [20] Traditionally, the common strategy to encourage participation in open government and open data often involved events such as innovation competitions $[11,13]$. Yet, program such as innovation competitions are often overstated $[11,21]$ and user participation for open data is often low [18]. For instance, the total number of visits to data.gov.uk from July 2012 to December 2015 was only $6,547,307$, averaging around 150,000 visits per month (https://data.gov.uk/data/site-usage\#totals). In October and November of 2015, data.gov had 357,905 visitors (https://data.gov/). The visitors of usaspending.gov in February 2011 was just under 10,000 , and the site costs $\$ 4$ million per year to maintain [29]. This situation could plausibly, as argued by Gurstein [8], depict a "data divide" in which efforts to extend access to data did not reach "everyone" since not "everyone" has access to infrastructure or skills that permit them to use open government and open data.

Public libraries are argued to have important roles in supporting an open government environment by, among other things, providing access and bridging the "data divide" $[4,5,17,27]$. A 2014 report by the Center for Technology in Government (CTG) strongly asserts that "The traditional and important role of public libraries as trusted information intermediaries provides a powerful platform for public libraries to be key facilitators in opening government," (Burke et al, [5], p. 6). The Center for Technology in Government recommends that public libraries focus on the demand side of open government and further argue that the public value of these libraries plays a significant role in the community open govemment ecosystem [5]. Public libraries promote increased digital inclusion to marginalized populations and those who face challenges using and benefiting from computers and the internet [23].

In this study, we concentrate on evaluating the role of public libraries to facilitate an open government environment by mediating the relationship between citizens and government ICT initiatives such as e-public services, open govemment and open data. We examine how citizens' perceptions of the value of public libraries determine their use of government ICT initiatives. Thus, we focus on two research questions: a) Do public libraries provide the value of facilitating users to engage open govermment? and b) How do public values and citizens' perceptions of those values in regard to public libraries determine citizen interaction with online government? We adopt the definition of Harrison et al [9] to identify open government environment as an ecosystem of interdependent relationships of government, innovators and citizens to promote transparency, accountability and participation To maintain interdependency, such ecosystems rely on 
intermediaries, such as public libraries to bridge connections and enable open government [5].

In addition, we adopt OECD's conceptualization of open government as transparency and accessibility of government services and information as indicators of open government. Thus, we consider citizens visiting government websites, acquiring information about government services, or using online databases as activities within an open government environment. Hence, we construct and justify our dependent variables as such.

We adopt the value-generating mechanisms from the public value framework of the Center for Technology in Government to define our variables. We specifically focus on two of their valuegenerating mechanisms, namely: a) enablement: providing means to enable the achievement of activities, and b) intrinsic enhancement: changing the environment in ways that are valuable to citizens [6]. To test for our hypothesis, we use data from a Pew Internet survey conducted on April 2015 called "Libraries and Technology Use" (http://www.pewinternet.org/datasets/).

Our paper is organized in five sections including the foregoing introduction. Section two presents our literature review, hypothesis and proposed model. In section three we describe our methodology. We present our analysis results and findings in section four and conclude our paper with discussion and concluding remarks in section five.

\section{LITERATURE REVIEW \& HYPOTHESIS DEVELOPMENT}

\subsection{Public Values, Public Libraries and Government ICTs Investments}

Government investment in ICT systems to transform public services is argued to create values more than just financial benefit [6] and is not just about delivering economic efficiency or effectiveness [19]. In terms of government ICT investment, Cresswell et al [6] argue that these values - coined "public values," a concept first put forward by Moore (1995) - relate to "the delivery of benefits directly to citizens and enhancing the value of government itself as a public asset" (Cresswell et al, [6], p. 2). They further argue for four value-generating mechanisms from which ICT investments can deliver public value, namely: increases in efficiency, increases in effectiveness, enablement and intrinsic enhancement [6].

One area of focus for govemment ICT investment is the modernization and transformation of public library services, including access to internet, software and digital content; such transformation is key in promoting digital inclusion $[12,26,30]$. Public libraries play a critical role as intermediaries in extending benefits of ICTs offered by the library or by other agencies [3,4,15$17,23,27]$. One impact of ICT investments in public libraries is the provision of online government services to citizens $[2-4,10,15$ $17,22,27]$.

Public libraries are seen as trusted information intermediaries that connect citizens to their government $[4,5,17]$. The modernization of public libraries through ICTs potentially enhances the perception of public values regarding use of the library as an environment to engage in open government [5]. Citizens presume certain public values when using public library services, including engaging with govemment in an online environment [2]. The perceived public values of public libraries determines if and how citizens use e-government [1].

Public values of government services (including public libraries) can be generated from two mechanisms: enablement and intrinsic enhancement [6]. Enablement refers to values generated from the capability of public libraries to provide means to access the open government environment through the use of computer, internet or mobile application provided by the public library [6]. In addition, citizens obtain public values from intrinsic enhancement, which is the way in which public libraries change so that citizens can connect with government in an environment of open government. For instance, because public libraries provide assistance to citizens seeking information, citizens are more competent in deciding what information they can trust or how to protect their security and privacy.

On the other hand, extant studies show that access and acceptance of information technology innovation was significantly affected by the behavioral aspect of users [25]. A large body of research evaluated the determinants of users' direct experience in using the innovation by focusing on the user's expectation about outcomes and belief in one's own ability to perform particular actions $[14,25]$. The concept of user expectation about outcomes is known as perceived-usefulness [7]. One's beliefs regarding the ability to perform a particular action is known as self-efficacy [14] and it affects the perceived ease-of-use in using and adopting technology innovation $[7,14,25,28]$.

Drawing from the above-mentioned argument, we posit that citizen engagement in open government through the mediation of public libraries is influenced by the citizen's perception of the public values of public libraries and the citizen's self-efficacy in using ICTs. We thus proposed our theoretical model in figure 1 below and explain our individual hypothesis in subsequent sections.

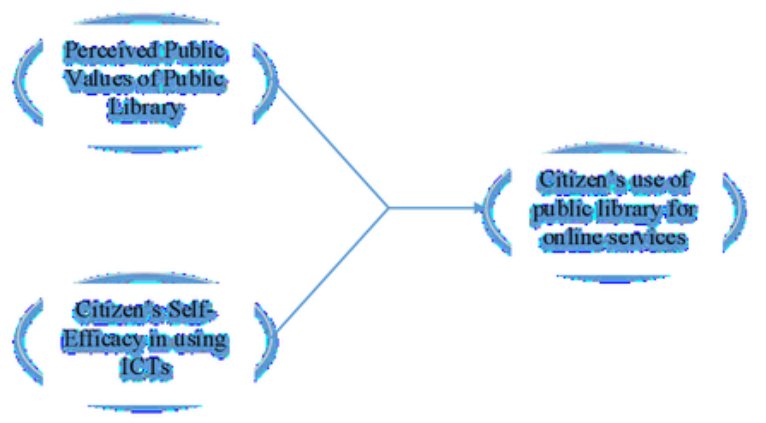

Figure 1. The Preliminary Model

\subsection{Hypothesis Development}

\section{a. Public Library Enabling Citizens to Use Open}

\section{Government}

As asserted by Burke et al [5], public libraries is the forefront of providing access to enable citizen's engagement with government and others. Public libraries have and can provide free public access to the technology needed for the citizens to engage with government $[4,17,22]$. On the other hand, providing free access does not necessary means that the citizens will use it to engage with government [10]. From broader perspective, providing access also means enabling the citizens to use of the technologies through literacy programs as well as helping citizens navigate the process of obtaining online government services and information [17].

Public libraries have always been regarded as the frontrunners in providing literacy training, including learning new technologies $[4,5,10,17]$. The technology literacy training provided by public libraries is argued to influence the citizen's engagement with 
government [17]. This is especially due to a funneling effect when citizens rely on libraries to engage with government since agencies closed local offices and moved their services and resources online [24].

Public libraries also possess knowledge that can inform and assist citizens navigating the processes of identifying information when engaging with government online [22, 27]. Public library enable citizens to engage with government in online environment by helping their patron to navigate the process of reducing the barriers of getting the information [22], such as reducing the effort to identify which information to trust. Hence, we propose the following hypothesis:

$\mathbf{H}_{1}$ : Public values provided by public libraries through the enablement significantly influence the likelihood of citizens using public libraries to engage in open government environment.

\section{b. Public Library Support Intrinsic Enhancement for Citizens to Use Open Government}

Public libraries also create public values through intrinsic enhancement, by changing the environment or circumstances that enhance the capability of citizens to engage with government [6]. We argue that public libraries create public values through intrinsic enhancement by assisting, offering guidance and helping their patrons. By offering help, public libraries changing the circumstances for citizens in engaging in open government in ways that are valued by the citizens. Other than providing access, the other significant role of public libraries is in providing assistance to their patron $[2,4,17]$.

The skilled librarians who are presumably familiar with multiple government systems offer assistance to their patron in interacting with government when requested [10], including personalized help to the patrons [27]. Public libraries assist patrons seeking information [22] and could help patron identifying how to protect their privacy and security. The skilled librarians also provide assistance in using the digital tools to whom who are not familiar to use it [22]. The librarians also offer assistance to help citizens carry out tasks involving government, such as seeking and requesting public records [22]. The assistance provided by public libraries influence the propensity of citizens in engaging with government, foremost in online environment [10, 17, 22, 27]. We thus propose the following hypothesis:

$\mathrm{H}_{2}$ : Public values provided by public libraries through intrinsic enhancement significantly in fluence the likelihood of citizens using public libraries to engage in open government environment.

\section{c. Self-Efficacy Influence the Citizen's Uses of Open Government}

Finally, a lot of research in information systems posit that access and acceptance of information technology innovation was significantly affected by the behavioral aspect of users [25]. The beliefs that one has the ability to perform particular action, also known as self-efficacy is argued to significantly influence the users' usage of technology innovations $[14,25]$. Consequently, we posit that:

$\mathrm{H}_{3}$ : Citizen's self-efficacy in using web and mobile applications significantly influence the citizens using public libraries to engage in open government environment.

\section{METHODOLOGY \\ 3.1 Sample and Distribution}

This study analyze the publicly available data (2015 Library and Technology Use) from the national survey conducted by the
Pew Internet via phone interviews on 2015. The national survey track 2,000 individuals in the US age 16 and above. This study used portion of the original dataset keeping only responses pertinent to this analysis. We extracted dataset $(\mathrm{N}=130)$ from respondents who used library website or mobile application to visit government website, obtain government services online or using online databases to get data.

Table 1 shows the distribution of the samples. Majority $42 \%$ of the respondents are between the ages of 16 to 45 , followed by those $(36 \%)$ whose age is from 46 to 65 . The majority of the respondents are white Americans $(77 \%)$ with majority $(60 \%)$ obtain minimum college degree or above. Only minority $(17 \%)$ of the respondents are not employed for pay while the greater part $(51 \%)$ are employed full time $(40 \%)$ or part time $(11 \%)$ with $45 \%$ of the respondents earn annual salary between $\$ 10,000$ to under $\$ 50,000$ and $44 \%$ of the respondents earn annual salary of $\$ 50,000$ or above.

Table 1. Distribution of Sample

\begin{tabular}{llc}
\hline & \multicolumn{1}{c}{ Categories } & $\%$ \\
\hline Employment & Employed Full Time & $40 \%$ \\
& Employed Part Time & $11 \%$ \\
& Retired & $26 \%$ \\
& Not employed for pay & $17 \%$ \\
& Self-Employed & $2 \%$ \\
& Other (Disabled, Student, etc.) & $5 \%$ \\
\hline Education & Less than or high school incomplete & $12 \%$ \\
& High school graduate & $28 \%$ \\
& College or two year associate degree & $25 \%$ \\
& Four years college or university degree & $20 \%$ \\
& Postgraduate & $16 \%$ \\
\hline Race & White & $77 \%$ \\
& Black or African American & $14 \%$ \\
& Asian or Pacific Islander & $3 \%$ \\
& Mixed Race & $3 \%$ \\
& Native American & $1 \%$ \\
& Other & $2 \%$ \\
\hline Income & Less than 10,000 & $11 \%$ \\
& 10 to under 30,000 & $27 \%$ \\
& 30 to under 50,000 & $18 \%$ \\
& 50 to under 100,000 & $25 \%$ \\
& More than 100,000 & $19 \%$ \\
\hline Age & $16-25$ years old & $16 \%$ \\
& $26-45$ years old & $26 \%$ \\
& $46-65$ years old & $36 \%$ \\
& $>65$ years old & $22 \%$ \\
\hline
\end{tabular}

\subsection{Variable Measurement}

a. Dependent variables: Citizens Engagement in Open Government Environment

We use two dependent variables to which both measuring the likelihood to engage in open government through the mediation of public library. Both of the dependent variables are a dichotomous variable gives value of 1 if the respondent respond YES and 0 if the respondent respond $\mathrm{NO}$.

- The first dependent variable named a 1 ovemment use, measure the likelihood that a respondent use 1 public library computer, internet or Wi-Fi connection to visit government website or get information about government services.

- The second dependent variable named is database use, measure the likelihood that a respondent use a public library website or mobile app to use online database. 
b. Independent Variables

1) Enablement: The Role of Public Libraries to Provide Means for Involvement in Open Government environment.

There are two variables representing the role of public library to enabling involvement in open government. These variable measures the role of public library to enable citizens involving in open government by helping them deciding what information they can trust and helping them leam how to use new technologies

- The first variable named as enable trust measures the role of public library to provide the means to help people decide what information they can trust.

- The second variable named as enable technolog 1 measures the role of public library to provide the means to help people learn how to use new technologies

Both of these variables are measured in 4-point ordinal scale, from: a lot (1) to not at all (4).

2) Intrinsic enhancement: The Role of Public Libraries to Change the Environment to enable involvement in open government environment

There are three variables representing the role of public library to create public value by providing intrinsic enhancement to the citizen to be involved in open government. These variables measures the respondents' perceptions on the role of public library that enhance the capability of citizens to engage in open government by offering program to teach about privacy and security, teach citizens how to use digital tools, and to do tasks involving govermments, or other institutions.

- The first variable named as intrinsic enhancement priacy and security measure whether public library should offer programs to teach patrons about protecting their privacy and security online. This variable is measured in 4-point ordinal scale ranging from: (1) should definitely do to (4) doesn't really matter.

- The second variable named as intrin 1 enhancement digital tools measure public library should offer programs to teach patrons how to use digital tools such as smartphones, mobile apps and computers. This variable is measured in 4point ordinal scale ranging from: (1) should definitely do to (4) doesn't really matter.

- The third variable named as intrinsic enhancement tasking measure respondents perception on whet $11 \mathrm{f}$ public library provide values by offering help to patrons on how to use the internet or mobile apps to carry out tasks involving governments or other institutions. This variable is a dummy variable with value of 1 given if respondent feels that public library help them carrying out tasks involving governments or other institutions and value of 0 is given if they feel otherwise.

3) User's Self-efficacy for Involvement in Open government environment

There are two variables measuring respondents' self-efficacy in getting involved with open government. These variables measure respondents' perception on the ease to carry out tasks with government and schools using internet and the ease for them to carry out the tasks using mob 1 apps. The construct to measure this variable is as follows "These days, institutions such as government and schools often expect that people will contact them or leam about them using the internet. How easy is it for you to carry out tasks with these institutions using the internet or email [mobile apps] (PEW Internet)" These variables are measured in 4-point ordinal scale ranging from: very easy (1) to not at all easy (4).

\subsection{Analysis Technique}

Given that the dependent variables are dummy variables, we use multivariate logistic regression to test our hypotheses on the causal relationship between the public value of public library and self-efficacy to the propensity of citizens to use public library to engage in open govermment. In addition, we also run series of crosstabular analysis and pairwise correlation to better understand the bivariate relationship; an analysis of relationship between two variables. Finally, we run some simulations to test our model from the logistic regressions.

\section{RESULTS AND FINDINGS}

The premise of this study is to understand the role of public libraries in enabling citizens to engage in open government environment. For that, we posit that citizens' perception upon the public values provided by public libraries will influence them to engage in certain activities within open government environment, such as: getting certain information about government services, visiting government website, or using online databases. Our analysis thus is conducted in two steps. First, we evaluate the cross tabulation between the independent and dependent variable to better understand the bivariate relationships among the variables. Second, we evaluate the causal relationship between all of the independent variables to the dependent variables.

\subsection{Correlating Public Values of Public Libraries with the Likelihood to Engage in Open Government Environment}

Our bivariate analysis was conducted in two forms: correlation and cross tabulation. Table 2 shows the results of pairwise correlation among the variables. The results show low to moderate correlation coefficient and the directions of the relationship varies Some variables also shown to have significant relation 1 ip among them. For instance, intrinsic enhancement by offering programs to teach people how to use digital tools (teach) has a significant, positive but moderate relationship (coeff. $0.401, \mathrm{p}<0.05$ ) with enablement by providing help to people how to use new technologies (teach). This suggestively means that an increase in the way public libraries providing means to enable citizens to learn about new technologies will also increase the citizens' perception on how public libraries change the environment by offering programs to use digital tools that are valued for the citizens.

In another instance, enablement by providing help to people on how to use new technologies (tech) is shown to have weak, negative but significant relationship (c1 ff. $-0.231, \mathrm{p}<0.05$ ) with the likelihood that respondents $1 \mathrm{e}$ a public library computer, internet or Wi-Fi connection to visit government website or get information about government services (govt).

This suggestively indicates that an increase in the way public libraries providing means to enable citizens to learn about new techno 1 gies does not necessarily increase the likelihood of citizens using 1 public library computer, intemet or Wi-Fi connection to visit government website or get information about government services. To further understand this result, we need to analyze the results from our cross tabulation linking the independent to the dependent variables. 
Table 2. Pairwise Correlation Matrix

\begin{tabular}{|c|c|c|c|c|c|c|c|c|c|}
\hline & govt & dbase & task & teach & trust & tech & prive & web & apps \\
\hline govt & 1.000 & & & & & & & & \\
\hline dbase & 0.213 & 1.000 & & & & & & & \\
\hline task & 0.290 & 0.038 & 1.000 & & & & & & \\
\hline teach & -0.144 & -0.102 & -0.068 & 1.000 & & & & & \\
\hline trust & -0.116 & 0.138 & 0.081 & 0.166 & 1.000 & & & & \\
\hline tech & -0.231 & -0.054 & -0.071 & 0.401 & 0.292 & 1.000 & & & \\
\hline prive & -0.002 & 0.032 & -0.169 & 0.002 & 0.024 & 0.081 & 1.000 & & \\
\hline web & 0.037 & -0.060 & 0.032 & -0.036 & 0.212 & -0.020 & -0.057 & 1.000 & \\
\hline apps & 0.017 & -0.140 & 0.036 & 0.157 & 0.252 & 0.042 & 0.015 & 0.546 & 1.000 \\
\hline
\end{tabular}

Table 3. Crosstab \& Chi-Square

\begin{tabular}{|c|c|c|c|c|c|c|c|}
\hline & & \multicolumn{3}{|c|}{ Government Website } & \multicolumn{3}{|c|}{ Using Online Database } \\
\hline & & Yes & No & Total & Yes & No & Total \\
\hline \multirow{3}{*}{$\begin{array}{l}\text { Intrinsic enhancement by } \\
\text { teaching digital tools }\end{array}$} & Definitely & $93.10 \%$ & $84.72 \%$ & $88.46 \%$ & $90.48 \%$ & $86.57 \%$ & $88.46 \%$ \\
\hline & Maybe & $6.90 \%$ & $12.50 \%$ & $10.00 \%$ & $9.52 \%$ & $10.45 \%$ & $10.00 \%$ \\
\hline & No & $0.00 \%$ & $2.78 \%$ & $1.54 \%$ & $0.00 \%$ & $2.99 \%$ & $1.54 \%$ \\
\hline \multirow{3}{*}{$\begin{array}{l}\text { Intrinsic enhancement by } \\
\text { teaching privacy } \\
\text { protection }\end{array}$} & Definitely & $81.03 \%$ & $80.56 \%$ & $80.77 \%$ & $79.37 \%$ & $82.09 \%$ & $80.77 \%$ \\
\hline & Maybe & $17.24 \%$ & $18.06 \%$ & $17.69 \%$ & $19.05 \%$ & $16.42 \%$ & $17.69 \%$ \\
\hline & No & $1.72 \%$ & $1.39 \%$ & $1.54 \%$ & $1.59 \%$ & $1.49 \%$ & $1.54 \%$ \\
\hline \multirow{2}{*}{$\begin{array}{l}\text { Intrinsic enhancement by } \\
\text { helping carry out tasks }\end{array}$} & Yes & $46.55 \%$ & $53.45 \%$ & $31.54 \%$ & $33.33 \%$ & $29.85 \%$ & $31.54 \%$ \\
\hline & No & $19.44 \%$ & $80.56 \%$ & $68.46 \%$ & $66.67 \%$ & $70.15 \%$ & $68.46 \%$ \\
\hline \multirow{4}{*}{$\begin{array}{l}\text { Enable citizens to decide } \\
\text { information to trust }\end{array}$} & A lot & $32.76 \%$ & $19.44 \%$ & $25.38 \%$ & $20.63 \%$ & $29.85 \%$ & $25.38 \%$ \\
\hline & Somewhat & $43.10 \%$ & $50.00 \%$ & $46.92 \%$ & $44.44 \%$ & $49.25 \%$ & $46.92 \%$ \\
\hline & A little & $15.52 \%$ & $19.44 \%$ & $17.69 \%$ & $23.81 \%$ & $11.94 \%$ & $17.69 \%$ \\
\hline & Not at all & $8.62 \%$ & $11.11 \%$ & $10.00 \%$ & $11.11 \%$ & $8.96 \%$ & $10.00 \%$ \\
\hline \multirow{4}{*}{$\begin{array}{l}\text { Enable citizens to use } \\
\text { new technology }\end{array}$} & A lot & $51.72 \%$ & $27.78 \%$ & $38.46 \%$ & $38.10 \%$ & $38.81 \%$ & $38.46 \%$ \\
\hline & Somewhat & $37.93 \%$ & $50.00 \%$ & $44.62 \%$ & $46.03 \%$ & $43.28 \%$ & $44.62 \%$ \\
\hline & A little & $5.17 \%$ & $12.50 \%$ & $9.23 \%$ & $11.11 \%$ & $7.46 \%$ & $9.23 \%$ \\
\hline & Not at all & $5.17 \%$ & $9.72 \%$ & $7.69 \%$ & $4.76 \%$ & $10.45 \%$ & $7.69 \%$ \\
\hline \multirow{4}{*}{$\begin{array}{l}\text { self-efficacy in using } \\
\text { intemet }\end{array}$} & Very Easy & $43.10 \%$ & $50.00 \%$ & $46.92 \%$ & $52.38 \%$ & $41.79 \%$ & $46.92 \%$ \\
\hline & Somewhat & $43.10 \%$ & $36.11 \%$ & $39.23 \%$ & $31.75 \%$ & $46.27 \%$ & $39.23 \%$ \\
\hline & Not too easy & $10.34 \%$ & $9.72 \%$ & $10.00 \%$ & $12.70 \%$ & $7.46 \%$ & $10.00 \%$ \\
\hline & Difficult & $3.45 \%$ & $4.17 \%$ & $385.00 \%$ & $3.17 \%$ & $4.48 \%$ & $385.00 \%$ \\
\hline \multirow{4}{*}{$\begin{array}{l}\text { self-efficacy in using } \\
\text { mobile apps }\end{array}$} & Very Easy & $25.86 \%$ & $29.17 \%$ & $27.69 \%$ & $28.57 \%$ & $26.87 \%$ & $27.69 \%$ \\
\hline & Somewhat & $34.48 \%$ & $37.50 \%$ & $36.15 \%$ & $38.10 \%$ & $34.33 \%$ & $36.15 \%$ \\
\hline & Not too easy & $18.97 \%$ & $15.28 \%$ & $16.92 \%$ & $17.46 \%$ & $16.42 \%$ & $16.92 \%$ \\
\hline & Difficult & $20.69 \%$ & $18.06 \%$ & $19.23 \%$ & $15.87 \%$ & $22.39 \%$ & $19.23 \%$ \\
\hline
\end{tabular}




\subsection{Cross-tabulation the Determinants}

The results from the cross tabulation displaying a distribution of cases by their values on two variables are shown in table 3 above. The results indicate that citizens who place a high public values on services and facilities of 1 red by public libraries are shown to have more inclination to $1 \mathrm{e}$ a public library computer, internet or Wi-Fi connection to visit government website or get information about government services. Respondents who perceive that public libraries providing public values through intrin sic enhancement by teaching to use digital tools $(93.10 \%$ yes; $84.72 \%$ no), intrinsic enhancement by teaching about privacy and security protection $(81.03 \%$ yes; $80.56 \%$ no), enabling citizens to decide which information to trust ( $32.76 \%$ yes; $19.44 \%$ no) and enabling citizens to use new technology $(51.72 \%$ yes; $2717 \%$ no) are suggestively associated with the likelihood to use 1 public library computer, internet or $\mathrm{Wi}-\mathrm{Fi}$ connection to visit government website or get information about government services (govt). The results indicate that percentage of respondents who perceive that public libraries provide public values by 1 helping them carry out tasks involving government and they use a public library computer, internet or WiFi connection to visit government website are lower $(46.55 \%)$ than percentage 1 respondents who perceive the same public value and do not use a public library computer, internet or Wi-Fi connection to visit government website $(53.45 \%)$. The results also show that respondents who considered themselves more eff 1 cious in using webs and mobile apps are less incline to use a public library computer, intemet or $\mathrm{Wi}-\mathrm{Fi}$ connection to visit government website. $50 \%$ of respondents who consider themselves have high efficacy in using internet and webs are those who do not use public libraries to visit government website, while $43.10 \%$ of these high efficacious respondents are those who use public libraries to visit government website
On the other hand, the cross tabulation results shown in table 3 indicate that in average the percentage of respondents who are less likely to use a public library website 1 m mobile app for using online database are higher than those who are more likely to use a public library website or mobile app for using online database. Even if the citizens perceived that public libraries provide public values through intrinsic enhancement by teaching about privacy and security protection $(79.37 \%$ yes; $82.09 \%$ no) or enable citizens to decide which information to trust $(20.63 \%$ yes; $29.85 \%$ no), these respondents do not necessarily use a public library website or mobile app for online database. On the other hand, providing public values through intrinsic enhancement by teaching citizens to use digital tools ( $90.48 \%$ yes and $86.57 \%$ no) or intrinsic enhancement by helping citizens carry out tasks involving government $(33.33 \%$ yes and $29.85 \%$ no) are associated with more likelihood to use a public library website or mobile app for online database. Likewise, respo 11 ents with higher self-efficacy in using internet or mobile apps are more likely to use a public library website or mobile app for using online database.

\subsection{The Determinants of Involvement in an Open Government Environment}

While results from correlation and cross tabulation could provide measurement of association between two variables, these techniques do not analyze the causal relationship among the variables. This section describes the results from multivariate logistic regression to better understand which variables predict the likelihood of citizens using public libraries to engage in open government environment (table 4).

The results indicate that there are two (significant or close t1 significant) predictors that affect the likelihood of citizens to 1 se a public library computer, internet or Wi-Fi connection to visit a government website or get information 1 out government services, and the propensity of citizens to use a public library website or mobile app to access online databases.

Table 4. Multivariate Logistic Regression

\begin{tabular}{|c|c|c|c|}
\hline Variables & code & $\begin{array}{c}\text { Use of } \\
\text { Government } \\
\text { Website }\end{array}$ & $\begin{array}{c}\text { Use of Online } \\
\text { Database }\end{array}$ \\
\hline Intrinsic enhancement in Conducting Tasks & task & $\begin{array}{c}1.41687 * \\
(.40873)\end{array}$ & $\begin{array}{l}.146916 \\
(.37172)\end{array}$ \\
\hline Intrinsic enhancement by teaching the use of digital tools & teach & $\begin{array}{r}-.332000 \\
(.50187)\end{array}$ & $\begin{array}{r}-.442815 \\
(.47160)\end{array}$ \\
\hline Intrinsic enhancement by teaching about privacy and security & prive & $\begin{array}{l}.473600 \\
(.34193)\end{array}$ & $\begin{array}{l}.307458 \\
(.38366)\end{array}$ \\
\hline Enablement in helping people decide information to trust & trust & $\begin{array}{r}-.180021 \\
(.20532)\end{array}$ & $\begin{array}{l}.483311 * \\
(.19920)\end{array}$ \\
\hline Enablement in helping people learn to use new technologies & tech & $\begin{array}{l}-.430311 * * \\
(.22404)\end{array}$ & $\begin{array}{r}-.196623 \\
(.22458)\end{array}$ \\
\hline Self-Efficacy in using internet for tasks involving government & web & $\begin{array}{l}.128079 \\
(.24593)\end{array}$ & $\begin{array}{l}.004517 \\
(.23073)\end{array}$ \\
\hline $\begin{array}{l}\text { Self-Efficacy in using mobile apps for tasks involving } \\
\text { government }\end{array}$ & apps & $\begin{array}{l}.027544 \\
(.18621)\end{array}$ & $\begin{array}{l}-.283328 \\
(.15092)\end{array}$ \\
\hline $\begin{array}{l}N \\
\text { Wald } \chi^{2}\end{array}$ & & $\begin{array}{r}130 \\
19.59\end{array}$ & $\begin{array}{r}130 \\
10.63\end{array}$ \\
\hline
\end{tabular}


Citizens' perceptions that public libraries provide public values through intrinsic enhancement, in the form of assistance in using the internet or mobile apps to access online govemments or other institutions, significi tly and positively influences the propensity of citizens to use a public library computer, internet or Wi-Fi connection to visit government websites or get information about government services (coeff. 1.417, $\mathrm{p}<0.05$ ). 'who perceived that perception that public libraries provide public v1 thes through intrinsic enhancement by providing help to patrons on how to use the internet or mobile apps to carry out tasks if 1 olving governments or other institutions is more likely to 10 a public library computer, internet or $\mathrm{Wi}-\mathrm{Fi}$ connection to visit government website or get information about government services. For a oneunit increase in citizen perceptionthat public libraries provide public 1 lues through intrinsic enhancement by providing help patrons on how to use the internet or mobile apps to carry out tasks involving governments or 1 ther institutions, the log odds of citizens using (versus not using) a public library computer, internet or WiFi connection to visit government websites or to get information about government services increases by 1.417.

The results also show that citizens' perception that public libraries provide public values by enabling people to learn to use technology is close to conventional threshold levels of statistical significance $(\mathrm{p}=0.055)$ 1 ut negatively influences the likelihood that the citizen will use a public library computer, internet or Wi-Fi connection to visit government websites or to get information about government services (coeff. -.4303). This means that for a one-unit increase in citizen perception of public libraries as providing public values by enabling people to $1 \mathrm{eam}$ to use technology, the log odds decrease for citizens using a public library computer, internet or Wi-Fi connection to visit government websites or to get information about government services.
On the other hand, when the 1 ependent variable measures the likelihood that citizens will use a public library website or mobile app to access online databases, the results indicate that only the citizen's perception that public libraries provide public values by enabling people to decide which information to trust is statistically significant at 0.05 levels. The results indicate that for every oneunit change in citizen perception about the public values in the form of public libraries enabling citizens to decide which inforn 1 ion to trust, the log odds of citizens using (versus not using) a public library website or mobile app to access online databases increase by .4833 . Likewise, the results also indicate that citizens who have high efficacy in usin 1 mobile apps for tasks involving government are less likely to use a public library website or mobile app to access online databases with the p-value falling just short of the conventional threshold levels of statistical significance $(p=0.06)$.

\subsection{Simulating Citizens' Propensity to Use Public Libraries to Engage in Open Government Environment}

We run several simulations to better understand the determinants of citizens' propensity to use public library internet, $\mathrm{Wi}-\mathrm{Fi}$, web and mobile apps to engage in an open government environment. If we set the value of the independent variables to the highest value (such as: should definitely teach digital tools, help citizens a lot to use new technology, etc), the probability of the respondents using public libraries to access the internet, Wi-Fi and mobile apps to use government websites is $75.10 \%$. If we alter the value of the independent variables, we will have different probability values.

Table 5. Simulation of the Logistic Regression Results

\begin{tabular}{|c|c|c|c|c|c|}
\hline & \multirow{2}{*}{$\begin{array}{c}\text { Value is } \\
\text { changed } \\
\text { to*) }\end{array}$} & \multicolumn{2}{|c|}{$\begin{array}{l}\text { Probability of Using Public } \\
\text { Library for Government } \\
\text { Website }\end{array}$} & \multicolumn{2}{|c|}{$\begin{array}{c}\text { Probability of Using Public } \\
\text { Library for Online } \\
\text { Database } \\
\end{array}$} \\
\hline & & $\begin{array}{c}\text { Yes } \\
{[\operatorname{Pr}(\mathrm{y}=1 \mid \mathrm{x})]}\end{array}$ & $\begin{array}{c}\text { No } \\
{[\operatorname{Pr}(\mathrm{y}=0 \mid \mathrm{x})]}\end{array}$ & $\begin{array}{c}\text { Yes } \\
{[\operatorname{Pr}(\mathrm{y}=1 \mid \mathrm{x})]}\end{array}$ & $\begin{array}{c}\text { No } \\
{[\operatorname{Pr}(\mathrm{y}=0 \mid \mathrm{x})]}\end{array}$ \\
\hline $\begin{array}{l}\text { Intrinsic enhancement by helping carry out tasks } \\
{[\text { yes }=1 ; \text { no }=0]}\end{array}$ & 0 & $42.24 \%$ & $57.76 \%$ & $46.82 \%$ & $53.18 \%$ \\
\hline $\begin{array}{l}\text { Intrinsic enhancement by teaching digital tools } \\
\text { [should definitely do }=1: \text { does not matter }=4]\end{array}$ & 4 & $52.69 \%$ & $47.31 \%$ & $21.27 \%$ & $78.73 \%$ \\
\hline $\begin{array}{l}\text { Intrinsic enhancement by teaching privacy } \\
\text { protection } \\
\text { [should definitely do }=1: \text { does not matter }=4 \text { ] }\end{array}$ & 4 & $92.58 \%$ & $7.42 \%$ & $71.95 \%$ & $28.05 \%$ \\
\hline $\begin{array}{l}\text { Enable citizens to decide information to trust } \\
{[\text { a lot }=1: \text { not at all }=4]}\end{array}$ & 4 & $63.73 \%$ & $36.27 \%$ & $81.30 \%$ & $18.70 \%$ \\
\hline $\begin{array}{l}\text { Enable citizens to use new technology } \\
{[\text { a lot }=1: \text { not at all }=4]}\end{array}$ & 4 & $45.33 \%$ & $54.67 \%$ & $36.11 \%$ & $63.89 \%$ \\
\hline $\begin{array}{l}\text { self-efficacy in using internet } \\
{[\text { very easy }=1: \text { not at all easy }=4]}\end{array}$ & 4 & $81.58 \%$ & $18.42 \%$ & $50.82 \%$ & $49.18 \%$ \\
\hline $\begin{array}{l}\text { self-efficacy in using mobile apps } \\
{[\text { very easy }=1: \text { not at all easy }=4 \text { ] }}\end{array}$ & 4 & $76.61 \%$ & $23.39 \%$ & $30.35 \%$ & $69.65 \%$ \\
\hline Threshold maximum: all values $=1$ & $\begin{array}{c}\text { all } \\
\text { maximum }\end{array}$ & $75.10 \%$ & $24.90 \%$ & $50.49 \%$ & $49.51 \%$ \\
\hline Threshold minimum: all values $=4$ or 0 & $\begin{array}{c}\text { all } \\
\text { minimum }\end{array}$ & $22.23 \%$ & $77.77 \%$ & $37.52 \%$ & $62.48 \%$ \\
\hline
\end{tabular}

*) if the value of the variable of interest is changed while holding other variables at the maximum value 
For instance, the probability of the respondents using a 1 ublic library computer, internet or $\mathrm{Wi}-\mathrm{Fi}$ connection to visit a government website or to get information about government services is at the lowest $(45.33 \%)$ if the respondents do not perceive that public libraries provide public values by providing new technologies. The results also show that the respondents do not place high value on intrinsic enhancement in the form of teaching library patrons about privacy and security protection. When all respondents perceive that public library programs which teach security and privacy protection are not necessary, the siril lation result shows that the probability that respondents will use a public library computer, internet or Wi-Fi connection to visit government websites or to get information about government services is the highest $(92.85 \%)$.

For the majority of respondents using a public library website or mobile app to use online databases, the results indicate the importance of providing public values through intrinsic enhancement by teaching citizens to use digital tools. Respondents who perceived that public libraries do not provide public values through intrinsic enhancement by teaching citizen 1 to use digital tools have higher probability $(78.73 \%)$ of not using a public library website or mobile app to access online databases. Similarly, respondents who perceived that public libraries do not provide public values through enablement by teaching them to use new technol 1 gies have the second highest probability $(63.89 \%)$ of not using a public library website or mobile app to access online databases. On the other hand, the simulation results about selfefficacy in using web or mobile apps show mixed results. For instance, when respondents express difficulty in using internet and web apps, the probability of these respondents using an online database is $50.82 \%$ (probability no: $49.18 \%$ ), while respondents who expressed difficulty in using mobile apps showed a $69.65 \%$ probability of not using online databases (probability yes: $30.35 \%$ ). These results plausibly indicate possible interactions among the predictors; thus, future research may test the influence of interactive variables to encourage the use of public libraries to engage in an open government environment.

\section{DISCUSSION \& CONCLUDING REMARKS}

\subsection{The Impact of Public Values of Public Libraries to Open Government Environment}

The results reveal that citizens' perceptions of public values provided by public libraries influence engagement in an open government environment. These values include researching certain information about government services, visiting government websites, or using online databases. Our results further accentuate the findings from a number of studies that postulate the significant role of public libraries in mediating the relationships between citizens and government in an online environment [to name few: $2,4,5,17,27]$. These studies, for instance, Jaeger et al [17], emphasize three significant roles of public libraries to extend the flow of information from government, namely: providing means to access, providing a way to understand the information, and providing a tool to navigate the e-government processes. On the other hand, these studies did not quantitatively test the causative relationships among these roles to the propensity of citizens to actually use public libraries to engage with govermment in an online environment. Our results demonstrate that enablement (allowing otherwise infeasible activity) and intrinsic enhancement (changing the environment to enhance the capability) are statistically significant in affecting the likelihood that citizens will use public libraries to engage with government online.

On the other hand, our findings indicate that citizens place different values upon the public library services that influence their engagement with government through the public library. For instance, our findings show that intrinsic enhancement, by helping the citizens carrying out tasks involving government, is a significant predictor, while intrinsic enhancement through offering classes on security and privacy protection is not a significant predictor in influencing citizen engagement in an open government environment. In another instance, enablement by helping citizens navigate which information to trust emerged as a significant predictor for the likelihood of citizens using online databases; on the other hand, helping them learn about new technologies does not emerge as a significant predictor.

Clearly, these findings demonstrate that not every public value provided by public libraries has a similar impact on stimulating the citizen's uses of public libraries for engaging with government online. Our simulation results further emphasize how the varying citizen values of the role of public libraries are influential in mediating the relationship between citizens and government. Thus, it is plausible to argue that this finding complements the argument on varying information behavior, different cultural expectations and attitudes about engagement with government in an online environment [17]. It is possible that these differences in behavior, cultural expectations and attitudes influence how patrons place values on the efforts provided by public libraries to mediate the relationships between the patrons and government. Consequently, enforcing a generic approach to encourage citizen interaction with government online through the mediation of public libraries could possibly produce less-than-ideal results. As such, government agencies should start to work collaboratively with public libraries in designing more effective ways of disseminating information [4, $17,27,24]$; particularly considering the "capacity of public libraries to meet the govemment information needs of their communities [24, p.478].

\subsection{Research and Practical Implications}

As a final point, we would like to draw our attention to the call from Burke et al [5] on how best public libraries take advantage of the opportunities to advance their roles in opening government. This because understanding how public library could best advance their roles depend on understanding the intricate and continuum of relationships between patrons, public libraries and govemment agencies [27]. In this regard, our findings could offer preliminary suggestions by pointing out that the citizens place different interests and values in their engagement with government online through the mediation of public libraries.

Consequently, as research implications, future study should always consider these differing values in understanding the continuum of relationships between patrons, public libraries and government agencies. Our findings point out that there are set of determinants that influence the action of patrons, public libraries and government agencies. Thus, give rise to the need for better understanding the determinants that influence each of the actor in the continuum of relationship between patrons, public libraries and government agencies. Additionally, given that each actor is driven by set of determinants, it suggest that researcher should employ more unconventional analytical methods that take into account both recursive and non-recursive relationships to test the continuum of relationships between patrons, public libraries and government; for instance, structural equation modelling or simulations. 
As practical implications, given that patrons place different values on the services offered by public libraries that affect their likelihood to engage with government online. Considering the varying information behavior of patrons [17], different cultural expectations and attitudes affecting the relationship between patrons, public libraries and government; Government agencies and public libraries should work collaboratively and always consider the different values and needs of the patrons in designing programs and services to help patrons engaging with government in online environment. Based on our findings, it is plausible to argue that programs or services designed and developed by considering the different values and needs placed by patrons will be more effective in inducing the engagement of patrons with government in online environment.

Finally, we call attention to some limitations to our study. While we found that citizens' perception of public values of public libraries influence their engagement with government online, this does not necessary mean that the citizens would be willing to access data that is not within their interests. The major contribution of this exploratory study is to highlight that citizens attach importance to public values offered by public libraries. As such that future research is needed to further ascertain the role of public libraries in stimulating citizens' motivation in engaging in open government. Furthermore, it is presumptuous to assume that the results from this study are sufficient for understanding citizens' motivation in using open government. On the contrary, the results from this study called for further study to understand citizen's motivation for engaging in open government. Likewise, we did not consider the influence of demographic factors in affecting the likelihood of public library patrons to engage with government in online environment. Since, different cultural expectations matter [17], future research could test the predictive power of demographic variables in affecting the model.

\section{ACKNOWLEDGMENTS}

This study use data from the 2015 Library and Technology Use Survey conducted by the Pew Internet. The data is extracted from http://www.pewinternet.org/datasets/april-2015-libraries-andtechnology-use/

\section{REFERENCES}

[1] Al-Hujran, O., Al-Debei, M.M., Chatfield, A. and Migdadi, M. 2015. The imperative of influencing citizen attitude toward e-government adoption and use. Computers in Human Behavior 53:

189-203. http://doi.org/10.1016/j.chb.2015.06.025

[2] Bertot, J.C. 2009. Public Access Technologies in Public Libraries: Effects and Implications. Information Technology and Libraries 28, 2: $\quad$ 81-91. http://doi.org/10.6017/ital.v28i2.3176

[3] Bertot, J.C., Jaeger, P.T., Langa, L.A and McClure, C.R. 2006. Drafted: I Want You to Deliver E-Government. Library Journal 131, 13: 34-37.

[4] Bertot, J.C., Jaeger, P.T., Langa, L.A. and McClure, C.R. 2006. Public access computing and Internet access in public libraries: The role of public libraries in e-government and emergency situations. First Monday 11, 9. http://doi.org/10.5210/fm.v1 1i9.1392

[5] Burke, G.B., Kowlowitz, A., Pardo, T.A., and Sutherland, M. 2014. Enabling Open Government for All: A Road Map for Public Libraries: Center for Technology in Government, University at Albany, Albany, NY. Retrieved 12/ 18, 2015, http://ctg.albany.edu/publications/reports/enabling open gov for_all

[6] Cresswell, A.M., Burke, G.B., and Pardo, T.A. 2006 Advancing the Return on Investment Analysis for Government IT: A Public Value Framework. Center for Technology in Government, University at Albany, Albany, NY.

[7] Davis, F.D. 1989. Perceived Usefulness, Perceived Ease of Use, and User Acceptance of Information Technology. MIS Quarterly 13, 3: 319-340. http://doi.org/10.2307/249008

[8] Gurstein, M.B. 2011. Open data: Empowering the empowered or effective data use for everyone? First Monday 16, 2. Retrieved December 18, 2015 from http://firstmonday.org/ojs/index.php/fm/article/view/3316

[9] Harrison, T.M., Pardo, T.A., and Cook, M. 2012. Creating Open Government Ecosystems: A Research and Development Agenda. Future Internet 4, 4: 900-928. http://doi.org/10.3390/fi4040900

[10] Heanue, A. 2001. In support of democracy: The library role in public access to government information. In Libraries \& democracy: The cornerstones of liberty, N. Kranich (ed.). American Library Association, Chicago, 121-128.

[11] Hellberg, A., and Hedström, K. 2015. The story of the sixth myth of open data and open government. Transforming Government: People, Process and Policy 9, 1: 35-51. http://doi.org/10.1108/TG-04-2014-0013

[12] Hendrix, J.C. 2010. Checking Out the Future. Retrieved December 23, 2015 from

http://www.cityoflarkspur.org/archives/78/American\%20Libr ary $\% 20$ Assoc $\% 20$ -

$\% 20$ Checking $\% 20$ Out $\% 20$ the $\% 20$ Future.pdf

[13] Hjalmarsson, A. and Rudmark, D. 2012. Designing Digital Innovation Contests. In Design Science Research in Information Systems. Advances in Theory and Practice, Ken Peffers, Marcus Rothenberger and Bill Kuechler (eds.). Springer Berlin Heidelberg, 9-27. Retrieved January 26, 2016 from http://ink.springer.com/chapter/10.1007/978-3-64229863-9_2

[14] Igbaria, $\bar{M}$., and Iivari, J. 1995. The effects of self-efficacy on computer usage. Omega 23, 6: 587-605. http://doi.org/10.1016/0305-0483(95)00035-6

[15] Jaeger, P.T. 2009. Public libraries and local e-government. In Handbook on research on strategies for local e-government adoption and implementation: Comparative studies. IGI Global, Hershey, Pa, 647-660. Retrieved January 26, 2016 from http://www.igi-global.com/chapter/handbook-researchstrategies-local-government $/ 21485$

[16] Jaeger, P.T., and Bertot, J.C. 2009. E-government Education in Public Libraries: New Service Roles and Expanding Social Responsibilities. Journal of Education for Library and Information Science 50, 1: 39-49.

[17] Jaeger, P.T., Gorham, U., Bertot, J.C., et al. 2014. Connecting government, libraries and communities: Information behavior theory and information intermediaries in the design of LibEGov.org. First Monday 19, 11. http://doi.org/10.5210/fm.v19i11.4900

[18] Janssen, M., Charalabidis, Y., and Zuiderwijk, A. 2012. Benefits, Adoption Barriers and Myths of Open Data and Open Government. Information Systems Management 29, 4: 258-268. http://doi.org/10.1080/10580530.2012.716740 
[19] Jørgensen, T.B., and Bozeman, B. 2007. Public Values An Inventory. Administration \& Society 39, 3: 354-381. http://doi.org/10.1177/0095399707300703

[20] Jurisch, M.C., Kautz, M., Wolf, P., and Krcmar, H. 2015. An International Survey of the Factors Influencing the Intention to Use Open Government. 2015 48th Hawaii International Conference on System Sciences (HICSS), 2188-2198. http://doi.org/10.1109/HICSS.2015.262

[21] Kuk, G., and Davies, T. 2011. The Roles of Agency and Artifacts in Assembling Open Data Complementarities. Retrieved January 26, 2016 from http://eprints.soton.ac.uk/273064/

[22] McDermott, P. and Richards, R. 2014. The Promise of Open Government, for the Nation and for Oregon. OLA Quarterly $16,3: 33-37$

[23] Sey, A., Coward, C., Rothschild, C., Clark, M., and Koepke, L. 2013. Public libraries connecting people for development: Findings from the Global Impact Study. Technology \& Social Change Group (TASCHA). Retrieved January 26, 2016 from https://digital.lib.washington.edu:443/researchworks/handle/ $1773 / 23885$

[24] Snead, J.T. 2014. Public Libraries, Evaluation, and Egovernment. The Library Quarterly: Information, Commonity, Policy 84, 4: 467-480. http://doi.org/10.1086/677782

[25] Straub, E.T. 2009. Understanding Technology Adoption: Theory and Future Directions for Informal Learning. Review of Educational Research 79, 2: 625-649. http://doi.org/10.3102/0034654308325896

[26] Swan, D.W., Grimes, J., Owens, T., et al. 2014. Public Libraries in the United States Survey: Fiscal Year 2012 Institute of Museum and Library Service, Washington DC.

[27] Taylor, N.G., Jaeger, P.T., Gorham, U., Bertot, J.C., Lincoln, R., and Larson, E. 2014. The circular continuum of agencies, public libraries, and users: A model of e-government in practice. Government Information Quarterly 31, Supplement 1: S18-S25. http://doi.org/10.1016/j.giq.2014.01.004

[28] Venkatesh, V., Morris, M.G., Davis, G.B., and Davis, F.D 2003. User Acceptance of Information Technology: Toward a Unified View. MIS Quarterly 27, 3: 425-478.

[29] Yau, N. 2011. Data.gov in crisis: the open data movement is bigger than just one site. The Guardian. Retrieved December 18,2015 from

http://www.theguardian.com/news/datablog/2011/apr/05/data -gov-crisis-obama

[30] Zickuhr, K., Rainie, H., Purcell, K., and Duggan, M. 2013. How Americans value public libraries in their communities. Pew Research Center: Internet, Science \& Technology, Washington DC. 


\section{The Values of Public Library in Promoting an Open Government Environment}

\section{ORIGINALITY REPORT}

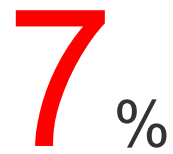

SIMILARITY INDEX
$\%$

INTERNET SOURCES
$1 \%$

PUBLICATIONS
$1 \%$

STUDENT PAPERS

PRIMARY SOURCES

$1 \quad$ www.baldwinlib.org

Internet Source

\section{Exclude quotes}

On

Exclude bibliography

On
Exclude matches

$<1 \%$ 